Louisiana State University

LSU Digital Commons

Faculty Publications

Department of Chemistry

9-7-1998

\title{
Metal-based chirality and spin state change in 16-electron CpML2 systems: A computational study of $\mathrm{CpW}(\mathrm{NO})\left(\mathrm{PH}_{3}\right)$
}

\author{
Kevin M. Smith \\ Universite de Bourgogne \\ Rinaldo Poli \\ Universite de Bourgogne \\ Peter Legzdins \\ The University of British Columbia
}

Follow this and additional works at: https://digitalcommons.Isu.edu/chemistry_pubs

\section{Recommended Citation}

Smith, K., Poli, R., \& Legzdins, P. (1998). Metal-based chirality and spin state change in 16-electron CpML2 systems: A computational study of $\mathrm{CpW}(\mathrm{NO})\left(\mathrm{PH}_{3}\right)$. Chemical Communications (17), 1903-1904.

https://doi.org/10.1039/a805176c

This Article is brought to you for free and open access by the Department of Chemistry at LSU Digital Commons. It has been accepted for inclusion in Faculty Publications by an authorized administrator of LSU Digital Commons.

For more information, please contact ir@lsu.edu. 


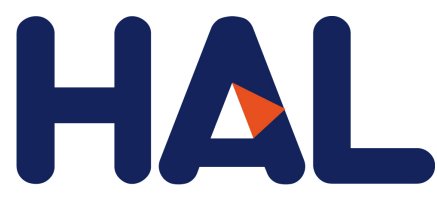

archives-ouvertes

\title{
Metal-based chirality and spin state change in 16-electron CpML2 systems: a computational study of $\mathrm{CpW}(\mathrm{NO})(\mathrm{PH} 3)$
}

\author{
Rinaldo Poli, Kevin Smith, Peter Legzdins
}

\section{To cite this version:}

Rinaldo Poli, Kevin Smith, Peter Legzdins. Metal-based chirality and spin state change in 16-electron CpML2 systems: a computational study of $\mathrm{CpW}(\mathrm{NO})(\mathrm{PH} 3)$. Chemical Communications, Royal Society of Chemistry, 1998, pp.1903-1904. 10.1039/A805176C . hal-03312479

HAL Id: hal-03312479

https://hal.archives-ouvertes.fr/hal-03312479

Submitted on 6 Oct 2021

HAL is a multi-disciplinary open access archive for the deposit and dissemination of scientific research documents, whether they are published or not. The documents may come from teaching and research institutions in France or abroad, or from public or private research centers.
L'archive ouverte pluridisciplinaire HAL, est destinée au dépôt et à la diffusion de documents scientifiques de niveau recherche, publiés ou non, émanant des établissements d'enseignement et de recherche français ou étrangers, des laboratoires publics ou privés. 


\title{
Metal-based chirality and spin state change in 16-electron $\mathrm{CpML}_{2}$ systems: a computational study of $\mathrm{CpW}(\mathrm{NO})\left(\mathrm{PH}_{3}\right)$
}

\author{
Kevin M. Smith, ${ }^{a}$ Rinaldo Poli*a and Peter Legzdins ${ }^{b}$ \\ a Laboratoire de Synthèse et d'Electrosynthèse Organometallique, Faculté des Sciences 'Gabriel', Université de Bourgogne, \\ 6 Boulevard Gabriel, 21100 Dijon, France. E-mail: Rinaldo.Poli@u-bourgogne.fr \\ ${ }^{b}$ Department of Chemistry, University of British Columbia, Vancouver, British Columbia, Canada V6T 1ZI
}

Density functional theory calculations indicate that $\mathrm{CpW}(\mathrm{NO})\left(\mathrm{PH}_{3}\right)$ possesses a planar triplet ground state, a result with significant implications for the inversion of configuration of $16 \mathrm{e}, \mathrm{d}^{6} \mathrm{CpML}_{2}$ species.

Several highly reactive $\mathrm{Cp} * \mathrm{~W}(\mathrm{NO}) \mathrm{L}$ intermediates $\left(\mathrm{L}=\mathrm{PMe}_{3},{ }^{1} \mathrm{PPh}_{3},{ }^{2}=\mathrm{CHCMe}_{3},{ }^{3} \mathrm{HCCPh}^{4-6}\right)$ have previously been shown to be generated by reductive elimination of $\mathrm{CMe}_{4}$ or $\mathrm{SiMe}_{4} \cdot \dagger$ These proposed 16 electron, $\mathrm{d}^{6} \mathrm{Cp} * \mathrm{~W}(\mathrm{NO}) \mathrm{L}$ species are not observed as they proceed to activate $\mathrm{C}-\mathrm{H}$ bonds, ${ }^{1-4}$ coordinate weak $\pi$-acceptor ligands, ${ }^{7}$ or engage in coupling and rearrangement reactions ${ }^{5,6}$ with available trapping reagents. Previous theoretical studies ${ }^{8-10}$ have demonstrated that the geometries and orbital energies of $16 \mathrm{e}, \mathrm{d}^{6} \mathrm{CpML}_{2}$ species are influenced by the bonding properties of their ligands. For example, $\pi$-donor ligands enforce a planar-at-metal conformation (i.e. the metal sits on the plane defined by the two ligands $\mathrm{L}$ and the $\mathrm{Cp}$ center of gravity), while pyramidal geometries are preferred for complexes containing either $\sigma$-donor ( $\pi$-neutral) or $\pi$-acceptor ligands. However, these studies were carried out using semiempirical methods and so were confined to the spin singlet energy hypersurface. The computational studies that we report here for the $\mathrm{CpW}(\mathrm{NO})\left(\mathrm{PH}_{3}\right)$ model system indicate that the spin state can play a previously unsuspected yet critical role in $16 \mathrm{e}, \mathrm{d}^{6} \mathrm{CpML}_{2}$ species.

The optimised geometries and relative energies of the singlet and triplet $\mathrm{CpW}(\mathrm{NO})\left(\mathrm{PH}_{3}\right)$ complexes are shown in Table 1 and Fig. $1 . \$$ The singlet is pyramidal at $\mathrm{W}$, as expected for a $\mathrm{CpML}_{2}$ species containing $\pi$-acceptor and $\sigma$-donor ligands. 9,10 However, triplet $\mathrm{CpW}(\mathrm{NO})\left(\mathrm{PH}_{3}\right)$ is calculated to possess a planar geometry at $\mathrm{W}$, and to be $3.3 \mathrm{kcal} \mathrm{mol}^{-1}(1 \mathrm{cal}=4.184 \mathrm{~J})$ more stable than the pyramidal singlet species. No significant variation in $\mathrm{W}-\mathrm{NO}$ bond distance is observed between the two different spin configurations since the $\mathrm{W}-\mathrm{NO} \pi$-bonding orbitals are fully occupied in both cases. ${ }^{17}$ There is, however, the expected ${ }^{18,19}$ slight overall extension of all bond lengths in the triplet, as well as an increase in CNT-W-P angle.

Table 1 DFT-B3LYP optimized geometries and energies for $\mathrm{CpW}(\mathrm{NO})\left(\mathrm{PH}_{3}\right)$

\begin{tabular}{lccccc}
\hline & \multicolumn{2}{c}{ Energy minima } & & \multicolumn{2}{c}{ Spin-crossover point } \\
\cline { 2 - 3 } \cline { 6 - 6 } Parameter & Singlet & Triplet & & Singlet & Triplet \\
\hline$\phi(N-W-C N T-P)$ & 125.0 & 180.0 & & 130.0 & 130.0 \\
W-CNT & 2.018 & 2.093 & & 2.023 & 2.107 \\
W-P & 2.482 & 2.522 & & 2.481 & 2.528 \\
W-N & 1.791 & 1.794 & & 1.792 & 1.795 \\
N-O & 1.251 & 1.252 & & 1.251 & 1.253 \\
CNT-W-P & 121.38 & 132.82 & & 122.37 & 129.37 \\
CNT-W-N & 128.55 & 133.55 & & 128.35 & 133.48 \\
P-W-N & 93.33 & 93.63 & & 95.36 & 85.64 \\
W-N-O & 175.34 & 176.71 & & 175.37 & 176.90 \\
Relative energy/kcal mol & 0 & -3.3 & & +0.8 & +0.8 \\
\hline
\end{tabular}

While triplet $\mathrm{Cp} * \mathrm{~W}(\mathrm{NO})\left(\mathrm{PR}_{3}\right)$ complexes have yet to be detected spectroscopically, the intermediacy of such a species where $\mathrm{R}=\mathrm{Ph}$ is consistent with kinetic measurements of the reaction between $\mathrm{Cp} * \mathrm{~W}(\mathrm{NO})\left(\eta^{2}-\mathrm{PPh}_{2} \mathrm{C}_{6} \mathrm{H}_{4}\right) \mathrm{H}$ and $\mathrm{CNCMe}_{3}{ }^{7,20}$ Replacing the $\mathrm{Cp}$ and $\mathrm{PH}_{3}$ ligands of the model complex with bulkier $\mathrm{Cp}^{*}$ and $\mathrm{PR}_{3}$ groups would be expected to enforce a larger CNT-W-P angle and a planar-at-W geometry, thereby further destabilising the singlet state. The steric shielding of the metal centre coupled with the expected reduced reactivity $^{21}$ of the high-spin configuration should impart additional stability, making triplet $\mathrm{Cp} * \mathrm{~W}(\mathrm{NO})\left(\mathrm{PR}_{3}\right)$ compounds reasonable synthetic targets. $\S$

In order to explore the role of the triplet spin state in the inversion of pyramidal, diamagnetic $\mathrm{CpML}_{2}$ species, further calculations were performed at various values of $\phi$ for both spin states (Fig. 1). The highest energy singlet conformation is the planar geometry $\left(\phi=180^{\circ}\right)$, leading to an inversion barrier of $7.7 \mathrm{kcal} \mathrm{mol}^{-1}$ along the singlet spin surface, which compares well with previous studies on other 16-electron systems. ${ }^{10}$ The energy of triplet $\mathrm{CpW}(\mathrm{NO})\left(\mathrm{PH}_{3}\right)$ increases relatively gradually as the geometry is distorted away from the planar-at-W conformation. As a result, the $\phi$ angle at which both spin states are equal in energy corresponds to a high degree of pyramidalization $\left(\phi \approx 130^{\circ}\right)$, only $0.8 \mathrm{kcal} \mathrm{mol}^{-1}$ higher in energy than the singlet ground state.

The one-dimensional energetic situation illustrated in Fig. 1 would suggest a low-energy inversion mechanism for diamagnetic, pyramidal $\mathrm{CpW}(\mathrm{NO})\left(\mathrm{PH}_{3}\right)$ via the spin triplet surface.II However, the two geometries at the spin-crossover point are significantly different (Table 1). According to the FranckCondon principle, both the geometries and the energies must be very similar for the spin flip process to occur. At the crossover

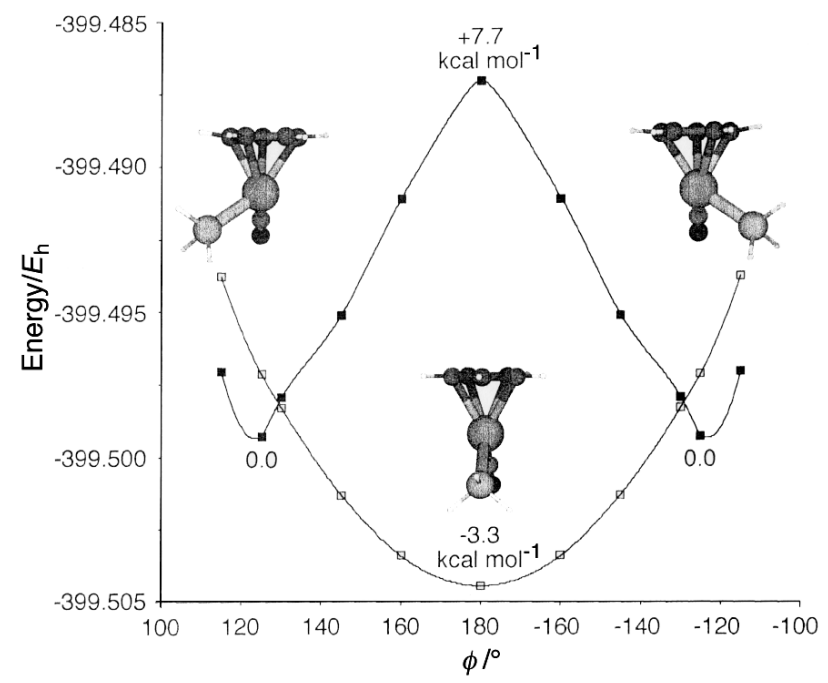

Fig. 1 B3LYP/LANL2DZ energies of optimized singlet ( $\square)$ and triplet ( $\square$ ) $\mathrm{CpW}(\mathrm{NO})\left(\mathrm{PH}_{3}\right)$ at various fixed dihedral $\mathrm{N}-\mathrm{W}-\mathrm{CNT}-\mathrm{P}(\phi)$ angles 
point $\left(\phi=130^{\circ}\right)$, the vertical excitation energies of singlet and triplet geometries (energy of the triplet configuration at the singlet geometry and of the singlet configuration at the triplet geometry) are 6.9 and $8.2 \mathrm{kcal} \mathrm{mol}^{-1}$, respectively. These numbers give an estimate of the upper bound of the spin flip barrier.\|

The energetic proximity of these vertical excitation energies and the inversion barrier along the singlet surface (within $\mathrm{ca}$. 1 $\mathrm{kcal} \mathrm{mol}^{-1}$ ) prohibits the definitive identification of the inversion mechanism (two-state vs. one-state) for the $\mathrm{CpW}(\mathrm{NO})\left(\mathrm{PH}_{3}\right)$ species. It is readily apparent, however, that the involvement of the triplet spin state represents a distinct and realistic alternative to a process restricted to the singlet spin surface, the only mechanism which has hitherto been considered for this class of compounds. Further experimental and theoretical work is unquestionably required to explore this possibility for $\mathrm{Cp} * \mathrm{~W}(\mathrm{NO}) \mathrm{L}$ species, as well as for $\mathrm{CpML}_{2}$ compounds in general.

Several 16e, $\mathrm{d}^{6} \mathrm{Cp} * \mathrm{M}\left(\mathrm{PR}_{3}\right) \mathrm{X}$ species have been invoked in intra- and inter-molecular $\mathrm{C}-\mathrm{H}$ bond activation reactions $(\mathrm{M}$ $=\mathrm{Ir}, \mathrm{X}=\mathrm{CH}_{3}+25 \mathrm{M}=\mathrm{Os}, \mathrm{X}=\mathrm{CH}_{2} \mathrm{SiMe}_{3} ; 26 \mathrm{M}=\mathrm{Ru}$, $\mathrm{X}=\mathrm{CH}_{2} \mathrm{CMe}_{3} ; 27 \mathrm{M}=\mathrm{Re}, \mathrm{X}=\mathrm{CO}, \mathrm{PMe}_{3} ; 28-30 \mathrm{M}=\mathrm{W}$ $\mathrm{X}=\mathrm{NO}^{1}$ ). In particular, much recent theoretical, synthetic, and mechanistic work has been focused on the low-temperature alkane $\mathrm{C}-\mathrm{H}$ bond activation reactions of the $\mathrm{Cp} * \operatorname{Ir}(\mathrm{P}-$ $\left.\mathrm{Me}_{3}\right)\left(\mathrm{CH}_{3}\right)^{+}$complex, ${ }^{31-34}$ but to the best of our knowledge, only one study has addressed the possible involvement of triplet species in this system. ${ }^{19}$ The role of the spin state in the reactivity of unsaturated $\mathrm{Cp} * \mathrm{~W}(\mathrm{NO}) \mathrm{L}$ species is currently under theoretical investigation. ${ }^{35}$

R. P. thanks the Région Bourgogne for supporting this research, and K. M. S. is grateful for a TMR Marie Curie Postdoctoral Fellowship.

\section{Notes and References}

$\dagger \mathrm{Cp}=\eta^{5}-\mathrm{C}_{5} \mathrm{H}_{5} ; \mathrm{Cp}^{*}=\eta^{5}-\mathrm{C}_{5} \mathrm{Me}_{5} ; \mathrm{CNT}=\mathrm{Cp}$ ring centroid.

\$Calculations were performed using Gaussian 94. ${ }^{11}$ The LanL2DZ basis set was employed to perform geometry optimisations with a density functional theory (DFT) approach. The three-parameter form of the Becke, Lee, Yang and Parr functional (B3LYP) ${ }^{12}$ was employed. The LanL2DZ basis set includes both Dunning and Hay's D95 sets for $\mathrm{H}$ and $\mathrm{C}^{13}$ and the relativistic electron core potential (ECP) sets of Hay and Wadt for the heavy atoms. ${ }^{14-16}$ Electrons outside the core were all those for $\mathrm{H}, \mathrm{C}, \mathrm{N}$ and $\mathrm{O}$, the $5 \mathrm{~s}, 5 \mathrm{p}, 5 \mathrm{~d}$ and $6 \mathrm{~s}$ electrons for $\mathrm{W}$ and the $3 \mathrm{~s}$ and $3 \mathrm{p}$ electrons for $\mathrm{P}$. The mean value of the first-order electronic wavefunction, which is not an exact eigenstate of $S^{2}$ for unrestricted calculations on open shell systems, was considered suitable for the unambiguous identification of the spin state. Ground state energies are based on complete geometry optimisations. The singlet geometry for $\phi=180^{\circ}$ was optimised with an imposed mirror plane. For all other values of $\phi$, the $\mathrm{C}_{5}$ ring of the $\mathrm{Cp}$ ligand was fixed as a regular pentagon, the degree of pyramidalisation was set at a specific N-W-CNT-P dihedral angle $(\phi)$, and the geometry was optimised with no other constrained parameters.

$\S$ For the use of steric bulky ligands in stabilising $\mathrm{Cp} * \mathrm{Ru}\left(\mathrm{PR}_{3}\right) \mathrm{X}$ species, see refs. 9,22 and 23 .

If For discussion of similar examples of 'two-state reactivity' see ref. 24 and references therein.

\| For a discussion of the problems inherent in estimating spin-crossover energies, see refs. 18, 21 and 24.
1 P. Legzdins, J. T. Martin, F. W. B. Einstein and R. H. Jones, Organometallics, 1987, 6, 1826.

2 J. D. Debad, P. Legzdins, S. A. Lumb, R. J. Batchelor and F. W. B. Einstein, Organometallics, 1995, 14, 2543.

3 E. Tran and P. Legzdins, J. Am. Chem. Soc., 1997, 119, 5071.

4 J. D. Debad, P. Legzdins, S. A. Lumb, R. J. Batchelor and F. W. B. Einstein, J. Am. Chem. Soc., 1995, 117, 3288.

5 P. Legzdins and S. A. Lumb, Organometallics, 1997, 16, 1825.

6 P. Legzdins, S. A. Lumb and V. G. Young, Jr., Organometallics, 1998, 17, 854 .

7 D. J. Burkey, J. D. Debad and P. Legzdins, J. Am. Chem. Soc., 1997, 119, 1139

8 C. C. Bickford, T. J. Johnson, E. R. Davidson and K. G. Caulton, Inorg Chem., 1994, 33, 1080

9 T. J. Johnson, K. Folting, W. E. Streib, J. D. Martin, J. C. Huffman, S. A. Jackson, O. Eisenstein and K. G. Caulton, Inorg. Chem., 1995, 34, 488.

10 T. R. Ward, O. Schafer, C. Daul and P. Hofmann, Organometallics, 1997, 16, 3207.

11 M. J. Frisch, G. W. Trucks, H. B. Schlegel, P. M. W. Gill, B. G. Johnson, M. A. Robb, J. R. Cheeseman, T. A. Keith, G. A. Petersson, J. A. Montgomery, K. Raghavachari, M. A. Al-Laham, V. G. Zakrzewski, J. V. Ortiz, J. B. Foresman, J. Cioslowski, B. B. Stefanov, A. Nanayakkara, M. Challacombe, C. Y. Peng, P. Y. Ayala, W. Chen, M. W. Wong, J. L. Andres, E. S. Replogle, R. Gomperts, R. L. Martin, D. J. Fox, J. S. Binkley, D. J. Defrees, J. Baker, J. P. Stewart, M. HeadGordon, C. Gonzales and J. A. Pople, Gaussian 94 (Revision E.1). Gaussian Inc., Pittsburgh, PA, 1995.

12 A. D. Becke, J. Chem. Phys., 1993, 98, 5648.

13 T. H. Dunning, Jr. and P. J. Hay, in Modern Theoretical Chemistry, ed. H. F. Schaefer, III, Plenum Press, New York, 1976, p. 1.

14 P. J. Hay and W. R. Wadt, J. Chem. Phys., 1985, 82, 270.

15 W. R. Wadt and P. J. Hay, J. Chem. Phys., 1985, 82, 284.

16 P. J. Hay and W. R. Wadt, J. Chem. Phys., 1985, 82, 299.

17 P. Legzdins, W. S. McNeil, K. M. Smith and R. Poli, Organometallics, 1998, 17, 615 .

18 P. E. M. Siegbahn, J. Am. Chem. Soc., 1996, 118, 1487.

19 M.-D. Su and S.-Y. Chu, J. Am. Chem. Soc., 1997, 119, 5373.

20 D. J. Burkey and P. Legzdins, manuscript in preparation.

21 R. Poli, Chem. Rev., 1996, 96, 2135.

22 B. K. Campion, R. H. Heyn and T. D. Tilley, J. Chem. Soc., Chem., Commun., 1988, 278.

23 H. E. Bryndza, P. J. Domaille, R. A. Paciello and J. E. Bercaw, Organometallics, 1989, 8, 379.

24 S. Shaik, M. Filatov, D. Schröder and H. Schwarz, Chem. Eur. J., 1998 4, 193.

25 B. A. Arndsten and R. G. Bergman, Science, 1995, 270, 1970.

26 P. W. Wanandi and T. D. Tilley, Organometallics, 1997, 16, 4299.

27 H. Lehmkuhl, M. Bellenbaum, J. Grundke, H. Mauermann and C. Kruger, Chem. Ber., 1988, 121, 1719.

28 R. G. Bergman, P. F. Seidler and T. T. Wentzel, J. Am. Chem. Soc. 1985, 107, 4358 .

29 J. M. Aramini, F. W. B. Einstein, R. H. Jones, A. H. Klahn-Oliva and D. Sutton, J. Organomet. Chem., 1990, 385, 73.

30 C. Leiva and D. Sutton, Organometallics, 1998, 17, 1700

31 D. L. Strout, S. Zaric, S. Niu and M. B. Hall, J. Am. Chem. Soc., 1996, 118, 6068 .

32 C. Hinderling, D. Feichtinger, D. A. Plattner and P. Chen, J. Am. Chem. Soc., 1997, 119, 10793.

33 H. F. Luecke and R. G. Bergman, J. Am. Chem. Soc., 1997, 119, 11538 .

34 S. Niu and M. B. Hall, J. Am. Chem. Soc., 1998, 120, 6169.

35 R. Poli, P. Legzdins and K. M. Smith, manuscript in preparation. 